\title{
Effect of Progressive Muscle Relaxation on The Level of Anxiety of Haemodialysis Patients at Muhammad Sani Hospital in Karimun
}

\author{
Rizki Sari Utami Muchtar ${ }^{1}$, Marlian $^{2}$ \\ ${ }^{1,2}$ Nursing, STIKes Awal Bros Batam, Indonesia \\ ${ }^{1}$ sariutami0784@gmail.com, ${ }^{2}$ marlian22@gmail.com
}

\begin{tabular}{|c|c|}
\hline & ABSTRACT \\
\hline $\begin{array}{l}\text { Keyword: } \\
\text { Hemodialysis; } \\
\text { Anxiety; } \\
\text { Progressive } \\
\text { Muscle } \\
\text { Relaxatio. }\end{array}$ & $\begin{array}{l}\text { Chronic kidney disease (CKD) has increased these years. Datas from } \\
\text { Muhammad Sani Hospital showed number of patients underwent } \\
\text { hemodialysis (HD) were } 34 \text { in } 2015 \text {, and has become } 77 \text { in April of } 2019 \text {. } \\
\text { One of the replacement therapy in CKD patient was hemodialysis. HD } \\
\text { intended to take over renal function to prolong in improve patient's quality } \\
\text { of life. Patients who undergo HD will experience anxiety caused by some } \\
\text { stressors, such as pain at the location of needle insertion. One of the } \\
\text { approach to overcome patients from the pain in HD is a non-farmacologic } \\
\text { one, which is progressive muscle relaxation (PMR). This study intended to } \\
\text { find the effect of PMR to the anxiety level of HD patients. It was a } \\
\text { quantitative study, with a quasi experiment using pre and post test without } \\
\text { control. Sampling method was purposive sampling and the size was } 20 \\
\text { respondents. We used Hamilton Anxiety Rating Scale (HARS) to detrrmine } \\
\text { the level of anxiety, and the intervention was PMR. Paired T-Test was } \\
\text { applied, with a normality test (Shapiro Wilk) previously done. We found } \\
\text { that the effect of PMR was significant, with a p-value 0,000 (<0,005) and } \\
\text { the mean of the anxiety level before and after intervention were } \\
\text { respectively } 22,65 \text { and } 16,30 \text { From all } 14 \text { parameters in the questionnaire, } \\
\text { from the highest score found in this study were respectively: Sleep } \\
\text { Disorder, Depression, Stress, Sensoric related Symptom and } \\
\text { Gastrointestinal related Symptoms. Based on this study,there was } \\
\text { significant effect of PMR in decreasing the anxiety level, and so it is } \\
\text { recommended to use PMR in overcoming anxiety problem in HD patients. }\end{array}$ \\
\hline
\end{tabular}

\section{A. INTRODUCTION}

Chronic renal failure (GGK) is a clinical syndrome due to decreased renal function, progressive and advanced enough, it occurs when the glomerular filtration rate is less than 50 $\mathrm{mL} / \mathrm{min}$. (Priyantari Dina Putri; Nurohkim, Nurohkim, 2018). Chronic renal failure is a progressive and irreversible disorder of renal function where the body's ability fails to maintain the metabolism and balance of liquids and electrolytes so uremia occurs. (Arika Indah Setyarini, 2018)

Chronic renal failure disease is the cause of the tenth ranked death in the world. Since 2011 the number of diseases caused by CRK reaches 850,000 people annually. According to data from the World Health Organization (WHO), GGK sufferers globally there are more than 500 million 
people and about 1.5 million people should undergo hemodialysis therapy. (Astuti, Anggorowati, \& Johan, 2017).

Increased renal failure patients occur in developed and developing countries. Based on research conducted by the Center for Disease Control and Prevention (CDC) in 2012, kidney failure was on the eighth sequence of deaths in the United States and an estimated 31 million inhabitants or about $10 \%$ of the population in the United States suffered renal failure. (Centers for Disease Control and Prevention, 2012)

The prevalence of renal failure in the United States according to data from the National Health and Nutrition Examination Survey (NHANES, 2013) by 14\% in which an increase in the previous year amounted to $12.5 \%$. Renal failure (GGK) is expected to continue to increase by 20 $25 \%$ annually in the population in the United States. The prevalence of chronic renal failure has also continued to increase in Taiwan $(2.990 / 1,000,000$ inhabitants), Japan $(2.590 / 1,000,000$ inhabitants). The pretreatment of chronic renal failure in Indonesia from year to year continues and the premature the baby, the more complex necessary care.

Increased. Data Indonesia Renal Registry (IRR) reports the number of GGK sufferers in Indonesia in 2016 as much as $98 \%$ of GGK is undergoing hemodialysis therapy and $2 \%$ undergo peritoneal dialysis. And the number of hemodialysis patients has increased from the previous year. The IRR report notes that the causes of GGK in patients undergoing hemodialysis are deabetic nephropathy (52\%), hypertension (24\%), congenital abnormalities (6\%), uric acid (1\%) and lupus disease (1\%). The number of hemodialysis patients from 2007 to 2016 experienced an increase of $2 \%$ especially in the year 2015 to 2016 . Based on the age of the most group patients at the age of 45-64. (Cahyani, 2016).

One of the replacement therapy in GGK patients is with hemodialysis (HD) which aims to replace renal function so as to extend the viability and improve the quality of life in people with GGK. The HD process requires a good enough HD Vascular access (AVH) to be obtained sufficiently large blood flow, the blood speed is required at $200-300 \mathrm{ml} / \mathrm{min}$ continuously during HD 4-5 hours. The American Journal of Kidney Diseases (AJKD) recompresses that GGK stage 4 and 5 patients should be fitted with vascular access for the preparation of HD action in the form of a subclavian catheter or double lumen and arteriovenous (Av) shunt or Cimino. (Kamasita et al., 2018).

In patients with chronic renal failure who undergo hemodialysis will experience anxiety caused by various stressors, including pain experience in the stirring areas when starting hemodialysis, financial problems, difficulties in maintaining occupational problems, disappearing sexual drive, depression due to chronic illness and fear of death.

In general, the process of HD in the hospital can cause psychological stress (anxiety) and physical disruptive system of neurology such as weakness, fatigue, anxiety, decreased concentration, disorientation, tremor, Iseizures, weakness in the arms, pain in the soles of the feet, behavioral changes (Ariani, Sitorus, \& Gayatri, 2014). Research on Kring (Sato et al., 2009) shows $61 \%$ of anxiety, depression and general health perception significantly contribute to HD patient quality of life.

In patients with chronic renal failure who undergo hemodialysis will experience anxiety caused by various stressors, including pain experience in the area of the decay when starting the HD, financial problems, difficulties in the problem of the work, sexual thrust disappeared, depression caused by chronic illness and fear of death

Patients undergoing HD, will usually experience a variety of physical problems and psychological problems. Physical problems are experienced such as nausea, vomiting, alopecia, dry skin and decreased body endurance. While the psychological disorder is an anxiety which arises as a side effect of HD, ranging from mild anxiety to heavy-scale anxiety even patients can experience panic. Physical changes due to side effects from HD tend to make the patient feel anxious, thereby affecting interpersonal relationships with other people and the life partner (Telussa, Rusnadi, \& Zeily Nurachman, 2019). Such psychological problems can affect the quality of life of GGK patients will be or are undergoing HD. 
Patients with CRCS will feel hopeless, anxious, worried about financial problems, loss of sexual function, burdens on families and loss of self-reliance. As a patient with chronic diseases, GGK patients experience many things on him. Patient's health orientation has a strong relationship to the patient's quality of life

That patients experience negative feelings such as sadness, despair, regret, disappointment, and shame. Ultimately, these negative feelings can lead to depression and anxiety. The research conducted by William reveals that quality of life is influenced by psychological factors such as negative feelings and anxieties. (Reda et al., 2014)

Patient anxiety arises from vague and diffuse concerns that are related to uncertain, helpless, and nonspecific objects. These anxieties are manifested directly through physiological changes such as (shaking, sweating, increased heartbeat, abdominal pain, shortness of breath) and such changes in behavior (restlessness, quick talk, startled reactions) and indirectly through the onset of symptoms as an attempt to resist anxiety (Weinzimer, 2012).

Anxiety occurs when a person feels threatened both physically and psychologically. A small reaction to a person with GGK appears at the time the patient is informed about the illness, the anxiety is generally about financial, concerns are not accepted in the family or community. The increase in this case in Indonesia occurs because one of them in people who often experience excessive anxiety, which can lower the immune system (Hawari-Meilud et al., 2017).

Individuals experiencing chronic renal failure and have been obliged to undergo hemodialysis will undergo many changes in his life. Changes in the changes, including selfadaptation to mobility limitations, roles in reduced communities, and decreased productivity, will affect their psychological conditions. In addition, a variety of changes in life can also impact the individual's perception of his life now including the quality of his life and his perception of himself including self-esteem.

\section{B. METHODS}

This research is a quantitative study using quasi experiment (SEMU experiments). By using pre-test and post-test Without Control. This research uses only one group of Tampa Comparators. The effectiveness of this treatment is assessed by comparing the results of pre-test and post Test therapy PMR sampling as many as 20 respondents with the criteria of GGK patients who undergo hemodialysis twice a week, clients who are willing to be a subject and cooperative to do actions,. Clients in full-conscious conditions can be well-oriented towards people, places and times, and can read and write. After 20 respondents were then interviewed by filling questioner HARS to see the level of anxiety before PMR therapy.

The study used the $\mathrm{T}$ test in pairs. Test data normality used to know data distribution. Test used is a test Shapiro-Wilk research then used different test pairs T. Test data normality used to know data distribution. The test used is a Shapiro-Wilk test.

\section{RESULT AND DISCUSSION}

Results of the analysis based on the results of 20 respondents and can be seen in the description, as follows:

Table 1. Characteristics of respondents relaxation therapy PMR

Based on gender, age, education, and old HD

\begin{tabular}{|c|l|c|c|}
\hline No & \multicolumn{1}{|c|}{ Variabel } & f & \% \\
\hline $\mathbf{1 .}$ & Gender & 10 & 50 \\
& Male & 10 & 50 \\
& Female & 1 & 5 \\
\hline $\mathbf{2 .}$ & Age & 1 & 5 \\
& $21-30$ & & 5 \\
\hline
\end{tabular}




\begin{tabular}{|c|l|l|l|}
\hline & $31-40$ & 4 & 20 \\
& $41-50$ & 4 & 20 \\
& $51-60$ & 6 & 30 \\
& $61-70$ & 5 & 25 \\
\hline 3. & Education & & \\
\hline & SD & 8 & 40 \\
& SMP & 5 & 25 \\
& SMA & 2 & 25 \\
& SI & & 10 \\
\hline $\mathbf{4 .}$ & Old HD & 5 & \\
\hline & Old HD & 6 & 25 \\
& $<1$ Year & 9 & 30 \\
& 1-2 Year & & 45 \\
\hline
\end{tabular}

(Source: Primary Data, 2017).

Based on Table 1, there are research results that the characteristics of respondents based on gender is 2010 male and 10 female, age with the most number is 51-60 years or (30\%), education level of most ELEMENTARY graduates are 8 respondents or (40\%) amounting to 8 or $40 \%$ and the old underwent HD $45 \%$ over two years.

The gender of the study took 10 male respondents and 10 female respondents, where women had more severe anxiety than two men in total. It is in line with Kaplan \& Sadock (2011). Anxiety disorders are often experienced by women compared to men. This is because women are more sensitive to their emotions, which ultimately affects their own feelings of severity. (Rokhman \& Supriati, 2018). From the results of the study gained that the youngest age of respondents 27 years and oldest is at the age of 67 years. The most age is at the age above 51-60 years or $30 \%$. The results of the study also showed that the average age of respondents was above 51 years. The age of a person seems to affect the way it performs in the disease. Anxiety disorders are more common in adulthood and more in women. (Sadock, B., 2007).

This level of research education is more than 8 people or $40 \%$ in line with research penelitian (Fajri Alfiannur, Fathra Annis Nauli, 2015) educational factors affecting one's anxiety level. Individual abilities are influenced by education level. The higher the level of education the individual is getting easier to think rationally and capture new information. (Rahmawati, Primasari Mahardhika; Musviro; Deviantony, 2018).

HD duration In this study obtained the number of respondents who experienced the most anxiety over two years amounted to 9 people or $45 \%$. In patients with GGK undergoing hemodialysis over a long period of time, symptom fatigue experienced $82 \%$ to $90 \%$ patients (Kautsar, Gustopo, \& Achmad, 2015). For patients with hemodialysis treatment GGK will prevent death, but do not cure or recover the GGK and unable to compensate for the loss of metabolic activities carried out by the kidney and the effects of the kidneys and its effect on the patient's quality of life. Patients with PGK must undergo this therapy 1-2 times by 4-5 hours each time during his life. (Rahmawati, Primasari Mahardhika; Musviro; Deviantony, 2018)

Table 2. HD Patient Anxiety frequency distribution before PMR therapy

\begin{tabular}{clcc}
\hline No & \multicolumn{1}{c}{ Anxiety } & n & \% \\
\hline 1 & Mild anxiety & 3 & 15 \\
2 & Moderate anxiety & 12 & 60 \\
3 & Severe anxiety & 5 & 25 \\
\hline & Total & 20 & 100 \\
\hline
\end{tabular}

(Source: Primary Data, 2017). 
Based on table 2 The results of analysis above shows that the average of the HD patient anxiety before the PMR therapy is in mild anxiety 3 respondents or (15\%), moderate anxiety as many as 12 respondents or (60\%) and severe anxiety as much as 5 respondents or (25\%).

In this research from the contents of a questionnaire HARS taken before the intervention of PMR researchers found respondents with the highest anxiety score of 33 and the lowest score of mild anxiety is 11 . Judging by the 14 anxiety parameters present in the questionnaire HARS, successive anxiety parameters that have the highest scores are: sleep disorders, depressive feelings, tension, sensory symptoms and Gastrointestinal symptoms. (Tanto, Liwang, Hanifan, \& Pradipta, 2014)

For sleep disorders, variables that often arise are: waking up at night, sleeplessness waking up with lethargy and difficult to start sleeping. Then for the feeling of depression, the variables that arise are: decreased pleasure in hobbies, loss of interest, sadness, waking up early and changing during the day.

The tension Parameter in this study raises the variables: The sleep is not calm, lethargic, can not rest quietly, easily surprised, easy to cry and restlessness. Furthermore, in the parameters of sensory symptoms obtained variables: blurred vision, pale face and weak feel. And the parameters of the gastrointestinal symptoms elicit variables: indigestion, before and after-meal pain, full flavor/bloating, nausea, vomiting, decreased weight and hard bowel movements.

Table 3. HD Patient Emergency frequency distribution after PMR therapy

\begin{tabular}{clcc}
\hline No & \multicolumn{1}{c}{ Anxiety } & n & \% \\
\hline 1 & Mild anxiety & 6 & 30 \\
2 & Moderate anxiety & 14 & 70 \\
3 & Severe anxiety & 0 & 0 \\
\hline & Total & 20 & 100 \\
\hline
\end{tabular}

(Source: Primary Data, 2017).

In mild anxiety as many as 6 respondents or (30\%) and moderate anxiety as much as 14 people or $(70 \%)$ While no more respondents experienced severe anxiety.

Table 4. Distribution result of average difference in anxiety level before and after therapy PMR

\begin{tabular}{lccccc}
\hline \multicolumn{1}{c}{ Variabel } & N & Mean & SD & p & Confidence Interval (95\%) \\
\hline Pre-test & 20 & 22,65 & 6,251 & 0,000 & $5,01-7,62$ \\
Post-test & 20 & 16,30 & 4,646 & & \\
\hline
\end{tabular}

\section{CONCLUSION AND SUGGESTIONS}

Based on the results of research and data processing that has been done by researchers on the influence of Progressive Muscle Relaxation against the anxiety of patients who undergo Hemodialisa in Muhammad Sani Karimun Hospital with respondents 20 people for two weeks, the conclusion that: the average age of respondents are the most above 50 years with the highest level of education elementary school. The average patient's anxiety before PMR therapy was 22.65 with a standard deviation of 6.251 . The average decline in patient anxiety after PMR therapy is 16.30 with standard deviation of 4,646. The average difference in patient's anxiety before and after the PMR therapy was obtained an average decrease in anxiety scores of 6.35 points. After the test of the paired $\mathrm{T}$, obtained the value $\mathrm{p}=0.001$ with Confidence Interval $95 \% \mathrm{f}$ ranging from 5.01 to 7.62. So there is a meaningful difference which means there is a therapeutic effect of PMR to the level of anxiety. 
The results of this research in line with the research conducted by Devi (2014) in North Sumatera, obtained the results that the PMR has a significant relationship with decreased anxiety in GGK patients undergoing hemodialysis (Devi \& Saharia, 2017). Supported again by research conducted by Astuti (2017) that the PMR is effective in reducing stress to GGK patients undergoing hemodialysis. (Astuti et al., 2017)

\section{ACKNOWLEDGEMENT}

Thank you to the respondents and puskesmas who have given the opportunity to be a research place as one of the supporting facilities. Thank to STIKes Awal Bros Batam who has been supporting the progress of this research so it can be a source to the fore in advancing science in the field of health.

\section{REFERENCES}

Ariani, Y., Sitorus, R., \& Gayatri, D. (2014). Motivasi dan Efikasi Diri Pasien Diabetes Melitus Tipe 2 Dalam Asuhan Keperawatan. Jurnal Keperawatan Indonesia, 15(1), 29-38. https://doi.org/10.7454/jki.v15i1.44

Arika Indah Setyarini. (2018). Issn 2303-1433. Jurnal Psikologi Pitutur, 3(2), 195-205.

Astuti, A., Anggorowati, A., \& Johan, A. (2017). Effect Of Progressive Muscular Relaxation On Anxiety Levels In Patients With Chronic Kidney Disease Undergoing Hemodialysis In The General Hospital Of Tugurejo Semarang, Indonesia. Belitung Nursing Journal, 3(4), 383-389. https://doi.org/10.33546/bnj.88

Cahyani, N. D. (2016). Hubungan Antara Tingkat Kecemasan dengan Tingkat Kualitas Hidup pada Pasien Gagal Ginjal yang Menjalani Hemodialisis di RSD dr.Soebandi Jember. Jurnal Pustaka Kesehatan, 4(2), 210-217. Retrieved from https://jurnal.unej.ac.id/index.php/JPK/article/view/3004

Centers for Disease Control and Prevention. (2012). Diabetes Report Card. Center for Disease Control and Prevention, 16. Retrieved from This report is required under the Catalyst to Better Diabetes Care Act of 2009, which is part of the Patient Protection and Affordable Care Act (Section 10407 of Public Law 111-148, hereafter called the Affordable Care Act). The act states that the report

Devi, D. M. R., \& Saharia, D. H. K. (2017). Effect of progressive muscle relaxation on post-operative analgesia. International Journal of Medical Research and Review, 5(2), 113-118. https://doi.org/10.17511/ijmrr.2017.i02.03

Fajri Alfiannur1, Fathra Annis Nauli2, A. P. D. (2015). Hubungan Antara Kecerdasan Spiritual Dengan Tingkat Kecemasan Pasien Gagal Ginjal Kronik Yang Menjalani Hemodialisa. JOM, 22(1), 9-18.

Hawari-Meilud, A., González-Reimers, E., Torres-Vega, A. M., Alvisa-Negrín, J., Quintero-Platt, G., MartínGonzález, M. C., ... Santolaria-Fernández, F. (2017). Síndrome metabólico y riesgo cardiovascular en la población diabética de El Hierro, Islas Canarias. Nutrición Hospitalaria, 34(3), 593. https://doi.org/10.20960/nh.256

Kamasita, S. E., Suryono, Nurdian, Y., Hermansyah, Y., Junaidi, E., Mohamat, \& Fatekurohman. (2018). Pengaruh Hemodialisis Terhadap Kinetik Segmen Ventrikel Kiri Pada Pasien Penyakit Ginjal Kronik Stadium V. NurseLine Journal, 3(1), 11-19.

Kautsar, F., Gustopo, D., \& Achmad, F. (2015). Uji Validitas dan Reliabilitas Hamilton Anxiety Rating Scale Terhadap Kecemasan dan Produktivitas Pekerja Visual Inspection PT. Widatra Bhakti. Seminar Nasional Teknologi 2015, 588-592. https://doi.org/10.1017/CB09780511792458

Priyantari Dina Putri; Nurohkim, Nurohkim, W. U. L. (2018). Hubungan Self Efficacy Dengan Kepatuhan Pembatasan Cairan Pada Pasien Gagal Ginjal Kronik Yang Menjalani Hemodialisis. Jurnal Kesehatan SAMODRA ILMU.

rahmawati, primasari mahardhika; musviro; deviantony, F. (2018). Efektifitas Progressive Muscle Relaxation (Pmr) Terhadap Penurunan Tekanan Darah Pada Penderita Hipertensi (Effectiveness Of Progressive Muscle Relaxation (Pmr) On Blood Pressure Reduction In Hypertension Patients). The Indonesia Journal of Health, (September).

Reda, M., Taddele, H., Afera, B., Bsrat, A., Abera, E., Hurrissa and Eshetu, ... References, C. (2014). Gambaran Tingkat Pengetahuan Dan Sikap Tentang Monitoring Kadar Gula Darah Mandiri Pada 
Penderita Dm Di Rs Pku Muhammadiyah Yogyakarta. 6(4), ثقتقتقن. https://doi.org/10.1590/s180998232013000400007

Rokhman, A., \& Supriati, L. (2018). Pengaruh Terapi Progressive Muscle Relaxation Terhadap Kecemasan Dan Kualitas Hidup Pada Pasien Diabetes Mellitus Tipe 2 Di RS Muhammadiyah Lamongan. Jurnal Riset Kesehatan Nasional, 2(1), 45. https://doi.org/10.37294/jrkn.v2i1.98

Sadock, B., \& S. (2007). Kaplan \& Sadock's Comprehensive Textbook of Psychiatry. In Kaplan \& Sadock's Comprehensive Textbook of Psychiatry, Çeviri Editörleri: Aydın H, Bozkurt A, Sekizinci Baskl, Güneș Kitabevi.

Sato et al., 2009. (2009). Anti-human Immunodeficiency Virus-1 Protease Activity of New. Chem. Pharm. Bull., 57(10), 1076-1080.

Tanto, C., Liwang, F., Hanifan, S., \& Pradipta, E. A. (2014). Kapita Selekta Kedokteran Edisi IV. In Jakarta : Media Aesculapius. https://doi.org/10.22146/buletinpsikologi.25163

Telussa, I., Rusnadi, \& Zeily Nurachman. (2019). Dynamics of $\beta$-carotene and fucoxanthin of tropical marine Navicula sp. as a response to light stress conditions. Algal Research, 41. https://doi.org/10.1016/j.algal.2019.101530

Weinzimer, S. A. (2012). Diabetes. In Schwartz's Clinical Handbook of Pediatrics: Fifth Edition (pp. 283290). 